\title{
A Study of Cooperative Learning and Independence: Impact on Children's Prosocial Behavior
}

\author{
Dema Yulianto ${ }^{1}$, Yufiarti' ${ }^{2}$ Ma'ruf Akbar ${ }^{3}$ \\ ${ }^{1,2,3}$ Doctoral Program, Department of Early Childhood Education \\ Universitas Negeri Jakarta, Indonesia
}

radendema@gmail.com

First draft received: 30 May 2019 Date Accepted: 1 Aug 2019 Final proof received: 31 Aug 2019

\begin{tabular}{|l} 
Abstract \\
The purpose of the study was to analyze the impact of cooperative learning with the PAP and STAD \\
methods and independence on young children's prosocial behavior. The research used an experimental \\
method. The sample consisted of 48 children. Data were analyzed with the 2-factor ANOVA variants, \\
followed by an interaction test between variables using the Tuckey test. The results show that there were \\
differences in the prosocial behaviors between the group of children with high and low independence. \\
Different method of cooperative learning used influenced young children's prosocial behavior diffierently. \\
There was also an interaction between cooperative learning and independence towards young children's \\
prosocial behavior. The implication of this research is that teachers as educators and counselors are \\
required to carry out systematic and ongoing prosocial education as a form of example for children. \\
Teachers wishing to teach with cooperative learning should choose a method appropriate to children's \\
characteristics. In addition, it is important to increase teachers' motivation in teaching. \\
Keywords: Cooperative learning; early childhood; independence; prosocial behavior \\
\hline \hline \\
To cite this paper (in APA style): \\
Yulianto, D., Yufiarti., \& Akbar. M. (2019). A study of cooperative learning and independence: Impact on \\
children's prosocial behavior. International Journal of Education, 12(1), 49-55. doi: $0.17509 / i j e . v 12 i 1.17522$
\end{tabular}

\section{INTRODUCTION}

Childhood is a very fundamental phase for individual development because of the enormous opportunities for personal formation and development. Therefore, early childhood education institutions must provide opportunities for children to develop every aspect of their development, including their cognitive, language, physical, social-emotional developments, as well as their independence (Gay \& Kirkland, 2003; Islakhiyah, 2003). Early childhood educators can encourage and improve children's development, especially in terms of their social and emotional development. Social development is needed by young children to learn to know and understand their environment. As stated by Soodak et al. (2002), early childhood education should provide real-life experiences so that children can gain new understandings such as by exploring the environment. When children are taught through programs, they also learn a lot of academic and social skills such as cooperation, consideration for others, and learning how to work in groups.

The current phenomenon, children spend a lot of time watching television programs, watching children's films on DVD and playing games on technology media. At the age of 4, children have favorite television programs and children's films that they enjoy repeatedly (Plowman \& McPake, 2013). For some parents, the most important thing is that their children are comfortable and safe at home to sit and be quiet. Finally, children become awkward when meeting children their age when they leave the house. The behavioral trends of young children who feel awkward in the social environment are seen to be increasing because they are supported by a pattern of parental guidance. Parents often feel worried if children play outdoors with their friends. As for when children spend time with their friends, there is a tendency for children to be selfish and want to be cared for by the people around them. Behaviors in early childhood are influenced by families and those closest to them such as caregivers or even families who live at home.

The above phenomenon is supported by the researchers' preliminary observations on the children at Gogorante Dharma Wanita Kindergarten and Ngasem Dharma Wanita Kindergarten while playing in class. Children rarely shared, cooperated, or tolerated their 
peers. In addition, interviews with classroom teachers about learning methods reveal that the teachers rarely applied learning methods such as role play, and they tended to use assignment-based learning. Therefore, it is not surprising that some children still had low prosocial behaviors. Prosocial behavior, according to Schonert-Reichl et al. (2012), can improve child sharing experiences, mutual assistance, and good cooperative behavior.

Prosocial behavior is concerned with the relationships with others, such as peers, teachers, parents and siblings. According to several studies, prosocial behavior will have a significant influence on children's cognitive development. As stated by Dalton (2010) prosocial behavior in infants and toddlers is determined by their thoughts on the behavior of adults around them as a form of social response. Prosocial behavior develops according to the age period (infants, toddlers, children, teenagers, and adults) and is related to social support from religion, family (father and mother), teachers and peers' friendships. In line with the statement above, Eisenberg, Fabes, and Spinrad (2006) argued that educators want their students to be generous, kind, and empathetic. The age of early childhood is very important because early prosocial behavior usually tends to continue until the following years. Therefore, we need effective learning to support children's development.

Prosocial behavior is highly valued by teachers and school personnel, as well as by the children themselves. In addition, prosocial behavior has been increasingly received special attention from educators, in part, because of interest in promoting positive aspects of function and psychological adjustment rather than emphasizing the maladaptive form of classroom behavior (Wentzel, 2015). However, teaching programs and interventions that directly promote the development of prosocial behavior are rare and often difficult to implement, especially given academic problems and other disciplines that also need to be addressed on a daily basis (Wentzel, 2015).

Researchers have identified factors that encourage the development of prosocial behavior in young children, among which are positively associated with perspective taking, thinking theory, and empathy (Caputi, Lecce, Pagnin, \& Banerjee, 2012; Renouf et al., 2010; Taylor et al., 2013); emotional regulation (Blair, Denham, Kochanoff, \& Wipple, 2004; Eisenberg et al., 1999). The quality of teacher and child's relationship has also been linked to prosocial behavior in children (Palermo et al., 2007). Likewise, teacher-student relations characterized by emotional closeness have been positively associated with forms of behavior that are socially competent and prosocial (Birch \& Ladd, 1998; Ladd \& Burgess, 2001; Silver, Measelle, Armstrong, \& Essex, 2005).

Prosocial behavior in early childhood contributes to school readiness and cognitive competence; skills such as taking perspective, empathy, and self-regulation contribute to the development of prosocial behavior and promote positive behavior in school. However, intervention studies that document causal relationships between positive and antecedent behavior and schoolbased consequences, and longitudinal studies documenting the long-term effects of prosocial behavior on cognitive outcomes are rare (Wentzel, 2015).

Teaching and strengthening positive social skills utilizing collaborative and cooperative learning activities can promote prosocial behavior in schools (Wentzel, 2015). Cooperative learning is a learning method in which students work together in small groups to develop their psychomotor, cognitive, and affective domains (Iserbyt, Madou, Vergauwen, \& Behets, 2011). This learning is marked by various forms of student interaction through physical activities (Barrett, 2005). To date, the majority of cooperative learning research has been tried in the context of the level of physical activity or skill performance and problem solving, and most of the research on cooperative learning has focused on increasing the level of physical activity.

This trend in research is reflected in the argument of Huang et al. (2017) that cooperative learning is the practice of applying social skills from face-to-face interactions in physical activity relationships to improve problem solving. Cooperative learning, especially with the STAD (Student Teams Achievement Divisions) method can be used to support emotional and social education. Besides supporting emotional-social education, it also supports children's prosocial behavior. This argument is in line with the finding of Finlinson's study (1997) showing that children who develop more prosocial behavior tend to be more socially competent than children who develop less prosocial behavior, where group play is very effective in facilitating prosocial behavior. The picture and picture (PAP) model is also very effective to make students more interested and motivated in learning activities. In this learning model, children do not only write, hear, and ask questions, but they also show pictures to the teacher in accordance with the subject matter.

Personality development is also important in developing children's prosocial behavior. It is related to children's independence, which is a psychosocial issue that arises continuously throughout the entire life cycle of an individual (Steinberg, 2002). Personal development arises in every situation that requires individuals to rely on and depend on themselves, such as when entering college outside the city, being accepted to work in a company, having a partner, or having problems with friends. The independence that an individual has will help him/her to be ready to face every situation and problem. This statement is supported by the research of Kusumaningrum and Andrianto (2012), indicating a relationship between independence and prosocial behavior in adolescents.

Based on the previous research results, the researchers would like to investigate the influence of the picture and picture (PAP) method and student team achievement divisions (STAD) on young children's independence and prosocial behavior. The results of this study are expected to increase knowledge about cooperative learning that can be made a reference for 
educators in improving the prosocial behavior of young children by using appropriate cooperative learning approaches.

\section{METHOD}

This research was conducted at Gogorante Dharma Wanita Kindergarten and Ngasem Dharma Wanita Kindergarten, Ngasem District, Kediri Regency, in East Java Province. The two kindergartens were purposively selected because of their cooperativeness in allowing the researchers to observe the teaching and learning. Based on the results of preliminary observation, the students in the two schools were heterogeneous, so the researchers assumed that the heterogeneity would affect the level of students' prosocial abilities.

This quasi-experimental study employed the (2x2) design with a matrix adapted Fraenkel \& Wallen (1996). The design of this study placed students in the experimental group and the control group, and both groups were given initial tests. The population of this study was all children in Group A kindergartens in Ngasem District, Kediri Regency, East Java province. Using multistage random sampling techniques, the researchers obtained 48 children as sample.

Data were collected using a scale for independence and prosocial behavior. Experiments were carried out in the form of cooperative learning using the PAP type learning approach in one group and using the STAD learning approach in the other group. Treatment was carried out once a week for each class for eight weeks in parallel, so that a total of 16 treatments were given to all classes. Each treatment was carried out for two hours. Data were analyzed with inferential analysis, followed by ANOVA 2-factor variant analysis, and proceeded with the interaction test between variables using the Tuckey test.

The scale used to measure the prosocial behavior was a rating scale (multilevel scale) with one to four interval values, starting from Highly Appropriate, Appropriate, Inappropriate, and Highly Inappropriate. With a rating scale, the raw data obtained were in the form of numbers, which were then interpreted qualitatively. Assessment was done in the form of observations of children's behavior, focusing on their ways of socializing and communicating for a certain period of time.

\section{RESULTS AND DISCUSSION}

In terms of prosocial behavior in the group of children treated with the PAP and STAD methods, based on the results of the two-way ANOVA, it was known that the value of $F(6.549)$ was greater than the value in the $F$ table (4.06). Thus, there were differences in young children's prosocial behavior between those in the group treated with PAP and STAD. This result is in accordance with the average score of young children's prosocial behavior in the STAD group (54.75) that was greater than the average score of the PAP group (52.83). 10 children in the STAD group or $41.7 \%$ obtained above-the-average score. On the other hand, there were 11 children or $45.9 \%$ in the PAP group who obtained the above-average score.
The results show that the prosocial behavior of young children treated with the STAD method was better than that of children taught with the PAP method. This difference indicates that although the basic principles of cooperative learning do not change, but in the selection of learning models the teacher must pay attention to the appropriate learning model in order to improve young children's prosocial attitudes. This is as Piaget (Uno, 2012) emphasized in cognitive theory that parts of a situation interact with all contexts of the situation. Separating subject matter into small components and studying them separately will lose the meaning of learning. This theory holds that learning is an internal process that includes memory, retention, information processing, emotions and other psychological aspects. The main objective in the cooperative learning model, according to Isjoni (2013), is that students can learn in groups with their friends by respecting opinions and giving other people the opportunity to express their ideas by expressing their opinions in groups.

Cooperative learning with the picture and picture model made the students more interested in following the learning process because this learning model uses attractive images. In addition, students tend to become more active because in learning using this model, they are required to find the right concepts by sorting or arranging images. This method is also different from the STAD type which gives more emphasis on activities and interactions among students to motivate each other, helping in mastering the subject matter in order to achieve maximum achievement. Both types of learning have different consequences in the formation of early childhood prosocial attitudes.

According to Gul (Khan \&Inamullah, 2011) the results of cooperative learning are the formation of attitudes and values, providing models of pro-social behavior, presenting alternative perspectives and perspectives, building coherent and integrated identities, and promoting critical thinking, reasoning, and behavioral problem solving. The implementation of cooperative learning strategies should be done on the basis of which strategy will be more optimal adjusted to the subject matter and the conditions and character of the students. In addition, other models in this cooperative learning strategy can also be combined so that learning is more interesting, and students can achieve maximum learning outcomes (Darwati, 2010).

The results of this study are consistent with (Broekhuizen, Mokrova, Burchinal, \& Garret-Peters, 2016) showing that domain-specific perspectives on child socialization seem to emphasize the importance of early emotional support and class organizations for the development of children's social and behavioral skills, especially during the transition to school basis, when increased demand is placed on children's socialemotional skills.

The results also indicate that the prosocial behavior of the young children was different depending on their levels of independence. This indication can be seen from the result of two-way ANOVA, where the value of $F(5.992)$ was greater than the $F$ value in the 
table (4.06). Thus, it was confirmed that there were differences in the prosocial behavior of the group of children with high independence and the group of children with low independence. This result is further confirmed by the average score of young children's prosocial behavior with high independence (54.71), compared to the average score of the group of children with low independence (52.88). 11 children (25.8\%) in the high-independence group obtained above-theaverage score, whereas only 10 children in the low independence group (41.7\%) got above-the-average score.

The results demonstrate that children who enter kindergarten should start overcoming their dependence on parents or caregivers. Children should begin to help themselves in such activities as using the toilet, wearing clothes, and putting on shoes. The initiative of children is very necessary because they need the role of the people around them to take initiative for themselves. Children should begin to be able to take care of themselves and to have the freedom to become an adult in the future. As explained above, children's early selfregulation skills are very important for their socialemotional well-being and academic achievement later.

Some benefits for the identification and further development of children's self-regulatory skills include: First, there is the potential to develop self-assessment on whether teachers promote children's self-regulation which can be directly and specifically related to what a teacher does in the classroom. The assessment can focus on whether teachers do the following things: 1) Demonstrating that self-regulation skills are very important for other aspects of children's learning and development (for example, if the teacher maximizes the child's self-regulating capacity during learning); and 2) Inviting a child so that $\mathrm{s} / \mathrm{he}$ is better able to manage him/herself during challenging situations (for example, by changing the learning environment) (Campbell, 2016). Differences in behavioral values in family and school environments reinforce differences in habituation in children. These differences certainly also create differences in each child in understanding and developing empathy that eventually affects the development of prosocial behavior (Taylor et al., 2013).

The next results, still using the ANOVA, indicate there that there was interaction between cooperative learning and independence towards young children's prosocial behavior. The ANOVA test shows that the value of $F$ was greater than $F$ value in the table (4.06). This result can be explained by the fact that the cooperative learning model was developed to achieve learning outcomes in the form of academic achievement, tolerance, accepting diversity, and developing social skills. The main principles in learning using cooperative models can form children to be more responsible individually or in groups. The main objective of cooperative learning models is that students can learn in groups by respecting opinions and providing opportunities for others to express their ideas by expressing their opinions in groups. Here, the environment is a very decisive factor on whether or not the level of independence of preschool children is achieved. A good environment increases the achievement of independence of children quickly. Cooperative learning environment produces certain characteristics in a child's personality which affect the child's independence.

Cooperative learning cultivates the characteristics of an independent child who can control himself, has a good relationship with friends, is able to deal with stress, has an interest in new things, and is cooperative with others. Lavasani et al. (2011) study shows that the implementation of cooperative learning by teachers in the classroom promotes social interaction between students and reduces impulsive behavior between them. Compared to students who were taught using traditional methods, the students taught with cooperative learning model showed better social behavior and less impulsive behavior, and they really had better social skills. Results from Blair, McKinnon, and Daneri's (2018) research also indicate that cooperative learning is generally effective in reducing problem behavior and fostering social and emotional skills in children in kindergarten classrooms. Thus, it is justifiable to argue that cooperative learning can improve competence and attention as well as the social-emotional skills and reduce the behavioral problems reported by teachers during kindergarten.

Overall, these interactions highlight the relevance of kindergarten's teaching and learning quality and the development of social-emotional skills from childhood to adulthood. It is important that cooperative education is designed to build social-emotional skills. This design includes support for the development of games created and facilitation of cooperative learning activities through deliberate interactions with classmates (Blair, McKinnon, \& Daneri, 2018). As mentioned above, the explicit goal of the PAP and STAD methods of cooperative learning is to support the development of independence and prosocial attitudes. In addition, cooperative learning can also be applied to support independence and social emotional education. The learning approach should focus on using small groups of students to collaborate in maximizing learning conditions to be independent and interact socially.

Next, the result of Tukey Test for young children's prosocial behavior treated with the PAP and STAD methods with high independence obtained a $Q$ value of $10.35>Q=4.04$ at $\alpha=0.05$. The result means that young children's prosocial behavior treated with the PAP cooperative learning was better than the prosocial behavior of children taught with the STAD method in the context of children with high independence. Children who have high independence are relatively able to face problems without being dependent on others. They always try to deal with and solve existing problems. Children with high independence are able to manage what they have, know how to manage time, walk and think independently accompanied by the ability to take risks and solve problems. The independence of young children can be developed by allowing children to have choices and express their choices early. Cooperative learning methods have different ways of encouraging 
them to act according to what they want and respect each choice made by them.

Effendi, Soetjipto, and Widiati (2016) recommend that teacher educators who will teach their student teachers to apply the cooperative learning model to: First, explain in detail the learning procedures to the student teacher. Student teachers are expected to fully understand what they have to do during class. Second, the teacher must consider suitable material that can be applied using the model. They also have to consider time management in implementing the model because the model requires a certain amount of time to achieve optimal results.

The results of this study also add to the literature the potential benefits of people-centered analysis to explore children's development. The level of independence of children will certainly have an influence on their choice to act, which results in differences in prosocial attitudes. Children are usually included in many social groups, and they face more opportunities to practice their social skills. In addition, students find themselves in school learning, the main activity is interpersonal communication rather than learning. Thus, the development of social skills, which are very important for successful communication from an early age, starts during kindergarten (Tarasova, 2016).

Finally, based on further test using the Tukey Test for young children's prosocial behavior with low independence given the STAD and PAP methods of cooperative learning, $Q=15.47<Q=4.04$ in the table at $\alpha=0.05$. The result means that the prosocial behavior of young children taught with the STAD type of cooperative learning was greater than that of children who were taught with the PAP method in the context of children with low independence. Children who have low independence certainly lack the initiative to act independently. They are very dependent on other people, to get help from people around him. In this context then the STAD method of cooperative learning is very helpful for children who have low independence to be able to be more social with others. With STAD method, children can work together with others, actively help and motivate to succeed together, and the interaction with other children will increase their ability to think. Slavin (2008) research shows that using STAD strategies in the classroom has many positive benefits for students. His research demonstrates how STAD cooperative learning can positively influence academic achievement, self-esteem, interpersonal skills, fellow relationships, attitudes toward school and class, and motivation to learn. When students were asked about teamwork skills, the majority strongly agreed that learning is made they acquire teamwork skills, increase their level of confidence, make the team strong and cohesive and improve their communication skills.

According to Rakhman and Syatroh (2014), STAD is one simple method in cooperative learning and is also an effective cooperative learning method. Like other learning methods, the STAD method has the advantage of having good interactions between students, increasing positive attitudes towards subjects, good attitude, improving interpersonal skills. The STAD method can make students happier in the learning process because students can work together with other friends in the group as a team to ask something that has not been understood, without being shy to ask. The STAD method in cooperative learning makes students eager to learn (Rakhman and Syatroh, 2015). The STAD model in early childhood teaching can improve student achievement better compared to conventional learning models at high, medium or low motivation. The STAD learning model can be an alternative learning model. However, the suitability of the material must be seen with the learning model that will be used. The use of alternative teaching and learning models needs to be considered as well so that students can more easily understand the material (Novianti, 2013).

\section{CONCLUSION}

Based on the results of the analysis and discussion, conclusions can be made as follows: (1) Both the PAP and STAD types of cooperative learning had influence on young children's prosocial behavior; (2) There was a difference in the prosocial behavior between groups of children with high independence and low independence; (3) There was interaction of influence between cooperative learning and independence on young children's prosocial behavior; (4) There was difference in the influence of cooperative learning with the PAP and STAD methods in children high and low independence. Specifically, the prosocial behavior of the children taught with the STAD method was better than that of the children taught with the PAP method for students with low independence; (5) There was difference in the influence of the PAP and STAD cooperative learning methods on the groups of students with high independence. The prosocial behavior of young children with high independence treated with the PAP cooperative learning method was better than that of the children taught with the STAD.

The implication of this research is that teachers as educators and mentors are required to carry out systematically and sustainably prosocial education as a form of example for children, thus impacting on increasing teaching motivation of teacher (Utomo, 2018). Teachers should also choose a teaching method that best suits the characteristics of their students in order to facilitate the development of students' prosocial behavior.

\section{ACKNOWLEDGEMENT}

This research is part of a doctoral dissertation research at the Department of Early Childhood Education, Universitas Negeri Jakarta. The authors would like to thank students and teachers and parents in Kediri Regency as respondents for this study for making this study of prosocial behavior related to learning and independence possible.

\section{REFERENCES}

Barrett, T. (2005). Effects of cooperative learning on the performance of sixth-grade physical education students. Journal of Teaching in Physical Education, 24, 88-102. 
Birch, S. H., \& Ladd, G. W. (1998). Children's interpersonal behaviors and the teacher-child relationship. Developmental Psychology, 34, 934946.

Broekhuizen, M. L., Mokrova, I. L., Burchinal, M. R., \& Garret-Peters, P. T. (2016). Classroom quality at pre-kindergarten and kindergarten and children's social skills and behavior problems. Early Childhood Research Quarterly, 36, 212-222.

Blair, K., Denham, S, Kochanoff, A., \& Wipple, B. (2004). Playing it cool: Temperament, emotion regulation, and social behavior in preschoolers. Journal of School Psychology, 42, 419-443.

Blair, C., McKinnon, R. D., \& Daneri, M. P. (2018). Effect of the tools of the mind kindergarten program on children's social and emotional development. Early Childhood Research Quarterly, 43, 52-61.

Caputi, M., Lecce, S., Pagnin, A., \& Banerjee, R. (2012). Longitudinal effects of theory of mind on later peer relations. The role of prosocial behavior, 48, 257270.

Dalton, W. B. (2010). Antisocial and prosocial behavior. Research Triangle Institute. Retrieved from http:// www.rti.org/pubs/rtipress/rosen/ Chapter7_Antisocial_and_Prosocial_Behavior.pdf

Darwati, Y. (2010). Penerapan teknik permainan bahasa untuk meningkatkan kemampuan menulis puisi di Kelas V SD Inpres Minakarya. Jurnal Kreatif Tadulako Online, 4 (12).

Effendi, A., Soetjipto, B.E., \& Widiati, U. (2016). The implementation of cooperative learning model tsts and carousel feedback to enhance motivation and learning outcome for social studies. IOSR Journal of Research \& Method in Education (IOSR-JRME), 6(3), 131-136.

Eisenberg, N., Fabes, R., Murphy, B., Shepard, S, Guthrie, I., Mazsk, P., Poulin, R., \& Jones, S. (1999). Prediction of elementary school children's socially appropriate and problem behavior from anger reactions at age 4-6 years. Journal of Applied Developmental Psychology, 20, 119-142.

Eisenberg, N., Fabes, R. A., \& Spinrad, T. L. (2006). Prosocial Development. In N. Eisenberg, W. Damon, \& R. M. Lerner (Eds.), Handbook of child psychology: Social, emotional, and personality development (pp. 646-718). Hoboken, NJ, US: John Wiley \& Sons Inc.

Finlinson, A. R. (1997). Cooperative Games: Promoting Prosocial Behaviors in Children. All Graduate Theses and Dissertations Paper 2404.

Fraenkel, J. R., \& Wallen, N. E. (1996). How to design and evaluate research in education. New York: McGraw-Hill.

Gay, G., \& Kirkland, G. (2003). Developing cultural critical consciousness and self-reflection in preservice teacher education. Theory Into Practice, 42 (3), 181-187.

Huang, M-Y., Tu, H-Y., Wang, W-Y., Chen, J-F., Yu, YT., \& Chou, C-C. (2017). Effects of cooperative learning and concept mapping intervention on critical thinking and basketball skills inelementary School. Thinking Skills and Creativity, 23, 207216.

Iserbyt, P., Madou, B., Vergauwen, L., \& Behets, D. (2011). Effects of peer mediated instruction with task cards on motor skill acquisition in tennis. Journal of Teaching in Physical Education, 30, 3150.

Isjoni. (2013). Cooperative learning: Efektivitas pembelajaran kelompok. Bandung: Alfabeta.

Islakhiyah, D. (2013). Implementasi pendidikan prososial (Studi pada TK Nurul Islam Purwoyoso Ngaliyan Semarang Tahun pelajaran 2012/2013). Undergraduate (S1) thesis, IAIN Walisongo.

Khan, G. N., \& Inamullah, H.M. (2011). Effect of student's team achievement division (STAD) on academic achievement of students. Asian Social Science, 7(12), 211-215.

Kusumaningrum, I., \& Andrianto, S. (2012). Hubungan antara kemandirian dengan perilaku prososial pada remaja. (Unpublished Bachelor's Thesis). UII: Yogyakarta.

Ladd G. W., \& Burgess, K. B. (2001). Do relational risks and protective factors moderate the linkages between childhood aggression and early psychological and school adjustment? Child Development, 72, 1579-1601.

Lavasani, M. G., Afzali, L., Borhanzadeh, S., Afzali, F., \& Davoodi, M. (2011). The effect of cooperative learning on the social skills of first grade elementary school girls. Procedia Social and Behavioral Sciences, 15, 1802-1805.

Novianti, I. (2013). Experimentation cooperative learning student team achievement division (stad) type viewed from learning motivation. Asian Journal of Education and E-Learning, 01(05), 272-276.

Plowman, L., \& McPake, J. (2013). Seven myths about young children and technology. Childhood Education 89 (1), 27-33.

Rakhman, A., \& Syatroh, I. L. (2015). The analysis of students' team achievement divisions (STAD) used in learning practice of translating and interpreting. ELTIN Journal, 3(II), 72-84.

Renouf, A., Brendgen, M., Parent, S., Vitaro, F., Zelazo, P., Boivin, M., Dionne, G., Tremblay, R., Perusse, D., \& Seguin, J. (2010). Relations between theory of mind and indirect aggression in kindergarten: Evidence of the moderating role of prosocial behaviors. Social Development, 19, 535-555.

Schonert-Reichl, K. A., Smith, V., Zaidman-Zait, A., \& Hertzman, C. (2012). Promoting children's prosocial behaviors in school: Impact of the "Roots of Empathy" program on the social and emotional competence of school-aged children. School Mental Health, 4, 1-21. http://dx.doi.org/ 10.1007/s12310-011-9064-7.

Silver, R. B., Measelle, J. R., Armstrong, J. M., \& Essex, M. J. (2005). Trajectories of classroom externalizing behavior: Contributions of child characteristics, family characteristics, and the teacher-child relationship during the school 
transition. Journal of School Psychology, 43, 3960.

Slavin, R. E. (2008). Cooperative Learning (Teori, Riset, dan Praktik). Bandung: Nusa Media.

Soodak, C. L., Erwin, E. J., WInton, P., Brotherson, M. J., ...Brault, L. M. J. (2002). Implementing inclusive early childhood education: A call for professional empowerment. TECSE, 22(2), 91-102.

Steinberg. J. R. (2002). Adolescence: sixth edition. USA: McGraw Hill Higher Education.

Tarasova, K. S. (2016). Development of socio-emotional competence in primary school children. Procedia Social and Behavioral Sciences, 233, 128-132.

Taylor, Z., Eisenberg, N., Spinrad, T., Eggum, N., \& Sulik, M. (2013). The relations of ego-resiliency and emotion socialization to the development of empathy and prosocial behavior across early childhood. Emotion, 13, 822-831.

Uno, H. B. (2012). Model pembelajaran. Jakarta: Bumi Aksara.

Utomo, H. B. (2018). Teacher motivation behavior: The importance of personal expectations, need satisfaction, and work climate. International Journal of Pedagogy and Teacher Education, 2(2), 333-342.

Wentzel, K. (2015). Prosocial behaviour and schooling. In Encyclopedia of Early Childhood Development. Retrieved from: http://www.childencyclopedia.com/prosocial-behaviour/accordingexperts/prosocial-behaviour-and-schooling 